\title{
Egy „ismeretlen” nyomtatott térkép 1522-ból \\ a Magyar Királyságról és az Oszmán Birodalom európai hódításairól
}

\author{
PLIHÁL Katalin
}

DOI: $10.30921 / G K .73 .2021 .5 .1$

Absztrakt: 1521. augusztus 29-én a magyar déli határt a hódítók támadásaitól védô védelmi várvonal legfontosabb várát - Nándorfehérvárt - két (1440, 1456) sikertelen oszmán ostrom után az I. Szulejmán vezette sereg elfoglalta. $E$ vár eleste után Európa hódítói elótt nyitva állt az út Magyarországra, illetve rajta keresztül a gazdag Német-római Birodalom felé is. A Drezdai Városi Levéltárban órzött, 1523. január 21. keltezésú levél melléklete volt az a térkép, amelyböl kitünik, hogy mely várkastélyokat és városokat vették be a törökök. Az e helyen bemutatott térkép két példánya közül a Münchenben örzött a II. világháború során megsemmisült, ezért az Országos Széchényi Könyvtár Térképtárában található mü ma az egyetlen példány. Vizsgálataink során fény derült arra, hogy a térkép szerkesztôje legalább két térképet illesztett össze, ezért a helyismeret hiányában e múvön tévesen két Tisza folyót találhatunk, és a két eltérố méretarányú térképból az erdélyi részletet tartalmazó rész topográfiailag sokkal pontosabb. Kiderült a továbbiakban az is, hogy e mú sokszorositása során már 1522-ben betúbeültetéses nyomdatechnikát használtak Itáliában. Bizonnyal röplapon, vagy korabeli újságban látta meg a napvilágot, mert a térképen ábrázoltak magyarázatok hiányában alig, vagy csak nehezen értelmezhetôk.

Abstract: Nándorfehérvár, the most important fortress of the defence line protecting the southern border of Hungary from the invaders' attacks was occupied by an army led by Suleiman I on 29 August 1521, after two unsuccessful Ottoman sieges (1440, 1456). After the fall of this fortress, the road to Hungary and to the rich Holy Roman Empire was open to the conquerors of Europe. Attached to the letter dated 21 January 1523, kept in the Dresden City Archives, was a map showing which castles and towns were occupied by the Turks. Of the two copies of the map presented here, the one kept in Munich was destroyed during World War II, so the print in the Map Collection of the National Széchényi Library is the only copy today. Investigations revealed that the map editor, having no local knowledge, put together at least two maps, which explains why there are two Tisza rivers in the map; further, the part showing Transylvania, coming from a larger-scale map, is topographically much more accurate. It also turned out that letter-embossing printing techniques were used in the reproduction of this work in Italy as early as 1522. Probably, the map was published in a leaflet or in a contemporary newspaper, because it is difficult to interpret the map without explanations.

Kulcsszavak: Magyar Királyság, Oszmán Birodalom, „kettős-Tisza”, betúbeültetés, térképek a korai röplapokon Keywords: Hungarian Kingdom, Ottoman Empire, doubled Tisza river, letter-embossing printing techniques, maps on the contemporary leaflets

A Tabula Hungarie megjelenése (1528) elôtt, annak ellenére, hogy e múvekról ma igen keveset tudunk, készültek térképek Európa e térségérôl is. Egy ilyen mappáról értesülhetünk az alábbi forrás alapján is. (Stadtarchiv Dresden - Drezdai Városi Levéltár)

"Ich send e[uer] g[naden] das Hunger land auf ein karten gedruckt, daraus zuvermerck[en], was der türk für Sloss unnd stet eingenommen." Ô h[ercegi] f[elségednek megküldöm Magyarország nyomtatott térképét, amiből kitûnik, mely várkastélyokat és városokat vették be a törökök. (Brichzin 1992) ${ }^{1}$. A fenti mondatokat is tartalmazó levelet 1523.

\footnotetext{
1 Hans Brichzin [1938-] levéltáros. In https://de.wikipedia.org/wiki/Hans Brichzin
}

január 21-én Nagyszakállú György² [1471-1539] Szász-Meissen hercegének küldte Doctor Dietrich von Werthern $^{3}$ [1468-1536] diplomata. Ố egy 12 oldalas levélben számolt be megbízójának az 1522. november 17-i nürnbergi birodalmi gyúlésen folytatott tárgyalásainak eredményérôl, valamint e jelentéshez csatolt egy Magyarországot ábrázoló térképet is. A legnagyobb sajnálatunkra György herceg a mellékletek közül az irattárba a Magyarországot ábrázoló térképet sem küldte vissza, ahogy arról Werthern aktára írt megjegyzéséból ma is értesülhetünk.

\footnotetext{
https:/hu.wikipedia.org/wiki/ Sz\%C3\%A1szorsz\%C3\%A1g uralkod\%C3\%B3inak list\%C3\%A1ja

3 https://www.deutsche-biographie.de sfz98003.html
}

\section{Ami az események hátterében volt}

1521 tavaszán Nándorfehérvár (Belgrád ${ }^{4}$ harmadik ostromára indult a frissen trónra került fiatal és becsvágyó I. (Nagy) Szulejmán [1494-1566] szultán (Veszprémi 2010). A török hadvezetés okulva e vár két korábbi sikertelen ostromából, és egy újabb esetleges kudarc elkerülése miatt, e katonai múveletben a teljes haderôt (250-300 ezer fó) bevetette. A gyorsabb haladás okán a felvonuló sereg két menetoszlopba rendezôdve folytatta útját kitűzött céljai felé. E hadmúvelet során nemcsak Nándorfehérvár, de a Száva folyó mellett szintén

\footnotetext{
${ }^{4}$ Nándorfehérvár ostromai: 1440, 1456, 1521 Ma: Beograd, Szerbia.
} 
stratégiailag fontos Szabács 5 várának elfoglalása is a kitûzött feladatok közé tartozott. Figyelemelterelésül kisebb, elsôsorban gyorsan mozgó lovas török csapatok a Havasalföldet, Erdélyt, és a Dráva-Száva közét támadták. Nándorfehérvár ostromát Piri Mehmed ${ }^{6}$ nagyvezír július 3-án kezdte meg, és augusztus 29-én négy heti ostrom után a hôsiesen és eredményesen védekezô védôk még életben lévô maradékai a várat feladták. Nándorfehérvár várának ostromával egy időben a Fekete-tenger felől érkezett meg a török flotta, amelynek fó feladata az lett, hogy megakadályozza a külsố segítség várba jutását, okulva az 1456-os eseményekból. Július 12-én pedig elfoglalták Zimony ${ }^{7}$ várát, így Nándorfehérvár körülzárása teljessé válhatott, az ostromlottak külsố segítségre már nem számíthattak. Július és augusztus között Jahjapasa Bali $^{8}$ [146?-1527] boszniai bég portyázó csapatai a Szerémségben több várat is elfoglaltak, ilyen sorsra jutott Barics, ${ }^{9}$ Kölpény ${ }^{10}$, Cserög ${ }^{11}$ és Szávaszentdemeter ${ }^{12}$ is. Az Ahmed pasa vezette ruméliai sereg, amely Szabács elfoglalására indult, a kitûzött feladatát már július 7-én teljesítette, így óket is Nándorfehérvár ostromához küldte a török hadvezetés (Pálosfalvi 2005).

Nándorfehérvár eleste után Szörényvár ${ }^{13}$, Scardona ${ }^{14}$, Tinnin ${ }^{15}$ és Orsova $^{16}$ is a hódítók kezére került, így az a külsố határvédelmi várrendszer, amely még 1521-ig kisebbnagyobb résekkel, de létezett, tovább feladatát már ellátni nem tudta (Cseh 2021). „Országunk - írta október 1-én II. (Jagelló) Lajos [1508-1526] magyar király a testvéréhez I. Zsigmond [1467-1548] lengyel királyhoz küldött levelében - most már nyitva áll a török

\footnotetext{
5 Ma Šabac, Szerbia.

6 https://hu.wikipedia.org/wiki/ Az Oszm\%C3\%A1n Birodalom nagyvez\%C3\%ADreinek list \%C $3 \% \mathrm{~A} 1 \mathrm{ja}$

7 Ma Beograd, Szerbia.

8 http://real.mtak.hu/106052/1/51_PDFsam Keletkutat\%C3\%A1s 2019-tavasz PRINT.pdf

9 Ma Barič, Szerbia.

${ }^{10}$ Ma Kulpin, Szerbia.

${ }^{11}$ Ma Čerevič, Szerbia.

12 Ma Sremska Mitrovica, Szerbia.

${ }^{13}$ Ma Drobeta-Turnu Severin, Románia.

${ }^{14}$ Ma Skradi, Horvátország.

${ }^{15}$ Ma Knin, Horvátország.

${ }^{16}$ Ma Orşova, Románia.
}

elôtt vízen és szárazon, és sohasem lehet boldog és nyugodt, míg Szabács és Nándorfehérvár az ellenség kezén marad." Nándorfehérvár volt a határvédelmi várrendszer legfontosabb és legnagyobb vára, amelyet hazánkban Magyarország kapujának, külföldön a latin kereszténység védôbástyájának tekintettek (Kiss 1889). A vár elestével minden felelôsen gondolkodó vezetố rémálma vált valóra, mivel szabaddá vált az út Magyarország belsô területei és a Német-római Császárság irányába is. Reményt e súlyos fenyegetettség elhárítására csak az európai közös összefogás adhatott volna, ám ez akkor már nem teljesülhetett, mivel a 16. század elejére a keresztény egyetemes közös felelősség gondolatát felülírta a nemzeti államok egymással vívott harcainak fontossága, illetve a lutheri reformáció ellen való fellépés. Késôbb a hatalmi harcokban Európa új hódítója I. Szulejmán szultán is jeles szerepet kapott, vele (elsôként az európai uralkodók közül) 1536-ban I. Ferenc [1494-1547] francia király lépett szövetségre, akinek korabeli címe „a legkeresztényibb király" volt.

Nürnbergben 1522. november 19-én a birodalmi gyúlésen a magyar delegáció vezetôje Macedóniai László [1480?-1536] nagyváradi püspök és diplomata az alábbi részleteket tartalmazó beszédében kért segítséget Magyarország számára is $(K$. Obermayer-Horváth 1959).

„Hốs Föherceg, Krisztusban tisztelendô Atyák, méltóságos Hercegek, minden rendbéli nemes Elökelók! Jóllehet nagyhírü gyülekezetetekben az itt jelenlevôk sürú sokasága mindennél nagyobb öröm számomra, hiszen oly alkalom tárult fel elôttem e hírneves tanács figyelmének felhívására, támogatásának megnyerésére, amelynél jobbat aligha remélhettem volna az égtôl, ... Mert keresztények vagyunk, e Szent Római birodalom szövetségesei és barátai. Ôseink már régtôl fogva, mintegy százötven éve örködnek a vártán nyugalmunk és a kereszténység közös nyugalma fölött vigyázva. És korántsem vértelen harcban óvták meg a keresztény határokat, nagyon is kegyetlen ára volt annak. Hiszen mindenféle csapatok tartásában, $s$ az ellenség állandó zsákmányolása és öldöklése közepette - futván el az évek - mi, a Magyar Királyság minden rendjei megfogyatkoztunk. Aztán a nagy pusztaságtól és elhanyagoltságtól rútan merednek felénk Magyarország legnemesebb vidékei, melyeken hány mezôt, hány várost, hány templomot, hány oltárt, kegyhelyet forgattak fel, vagy változtattak világi célúvá szentségtörô kezek? ...De most a szabad átkelés a Dunán és a Száván ellenség kezében van. Mivel mindezeket elvesztettük, csak a ti segitségetek menthet meg bennünket. Ha hagyjátok, hogy a Tiszát és a Drávát is megszerezzék, tudomásom szerint nem lesz hajózható folyó egész Alsó-Németországban a Rajnáig, hogy az ellenség csapatait akadályozza, visszatartsa. ... Ezért hát idézzétek fel magatokban, milyen pajzsa, milyen bástyája volt eddig Magyarország Németországnak, s mennyit érnek a magyarok fegy verei egyrészt az igaz, hitnek, másrészt a ti nyugalmatoknak, és mit értek ezután még, ha megmenekül. Ne vegyétek semmibe vagyonotokat és nyugalmatokat, mert ez teljességgel Magyarország megmenekülésétől függ. Ne vessétek meg szomszédotok állapotát, mert ha nyomorúságos, mert ha veszendô, a ti romlásotokkal fenyeget. ... mikor Németország fejedelmei nemcsak az ellenséges fegyverekkel veszélyeztetett Friaul, Krajna, Karinthia, Stájerország számára hoztak békét, de a régi szennytôl elrútitott többi keresztény területet is hajdani fényükbe állítják vissza, és a förtelmes szolgaság annyi éven át tartó elnyomatása után felszabadítják." (Klaniczay 1982) A magyar küldöttség december végén távozott Nürnbergból, miután megkapták Ferdinánd osztrák főherceg 1522. december 22-én írt levelét, amelyben ô csak 4 ezer német gyalogos katona küldésére tett ígéretet.

Véleményünk szerint a Werthern által György hercegnek küldött térkép bizonnyal az alábbi lehetett, mivel azon a korábbi hódítások mellett az 1521-ben újonnan megszerzett várak is félhold jelzéssel szerepeltek. E cím nélküli térképbôl eredetiben ma csak 


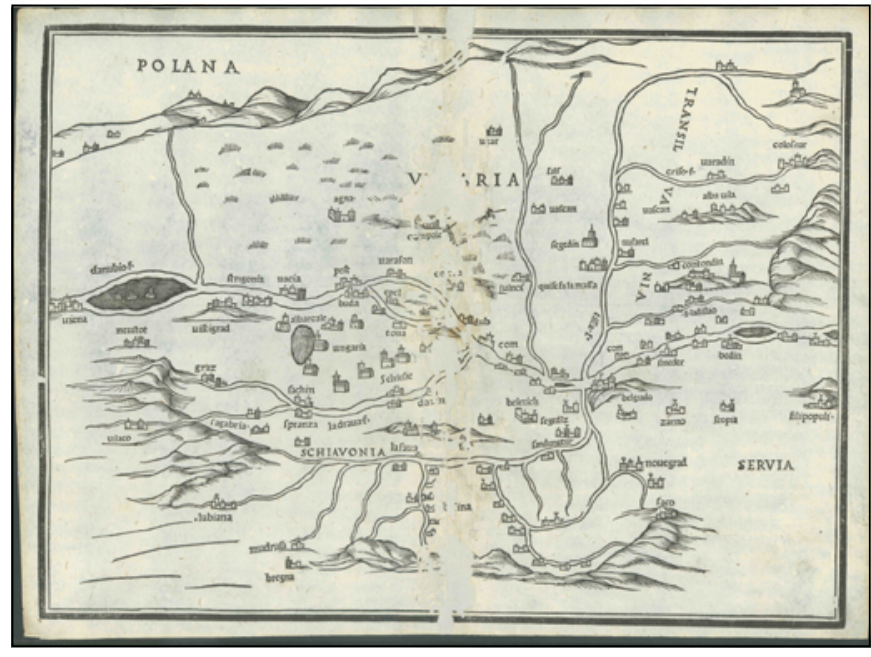

1. ábra. Cím nélküli térkép az OSZ gyüjteményébốl

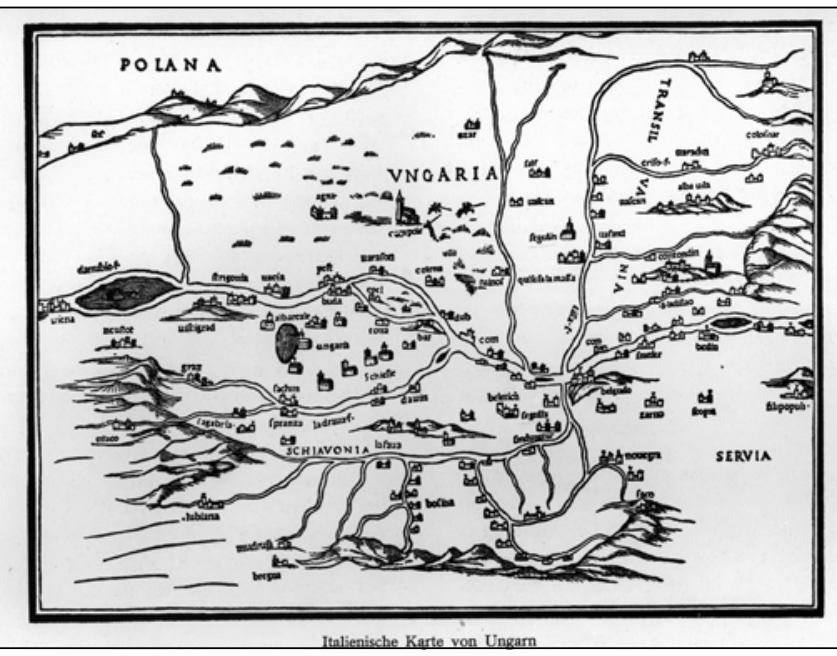

2. ábra. Az 1. ábrán látható térkép Münchenben elpusztult példánya

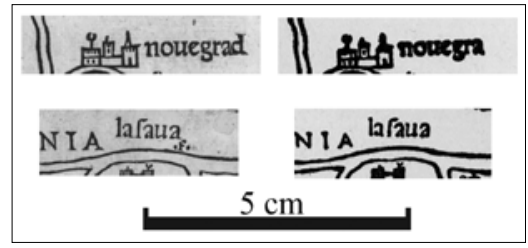

3. ábra. Az 1. és 2. ábrán látható térképek részletei. (A bal oldali részletek az OSZK példánya alapján készültek, amelynek ma a fizikai állapota ugyan rosszabb, de egykor a jobb állapotú nyomódúcról készült.)

egy példányt ismerünk, ez az Országos Széchényi Könyvtár Térképtárában található. ${ }^{17}$ (1. ábra)

1945 elốtt e múbôl Münchenben volt még egy példány, de az a 2 . világháború alatt elpusztult. (2. ábra) (Oberhummer-Wieser 1906)

E két térkép tartalma, - ahogy az az alábbi képen is megfigyelhetó-, egymástól csak minimálisan különbözött. Ugyanakkor azt is megállapíthattuk, hogy e fametszetes térképen a földrajzi nevek betúbeültetéssel kerültek a nyomódúc felszínére. A nyomdai öntött ólombetûk a használat következtében megkoptak, így lenyomatuk vastagabb lett, ahogy az az egykori müncheni példányról készült fényképen látható. (3. ábra)

\section{A szerkezeti vizsgálatok eredménye}

A térképrészleten sárga szövegkiemelővel jelöltük a vizsgált településeket. A piros keretes részlet a vizsgált, míg a fekete keretes részlet a mai modern térkép szerinti. Az összehasonlításul

\footnotetext{
${ }^{17}$ Jelzete: TR 207, címe nincs, a térképen a készítố neve sem szerepel.

Mérete $272 \times 374 \mathrm{~mm}$.
}

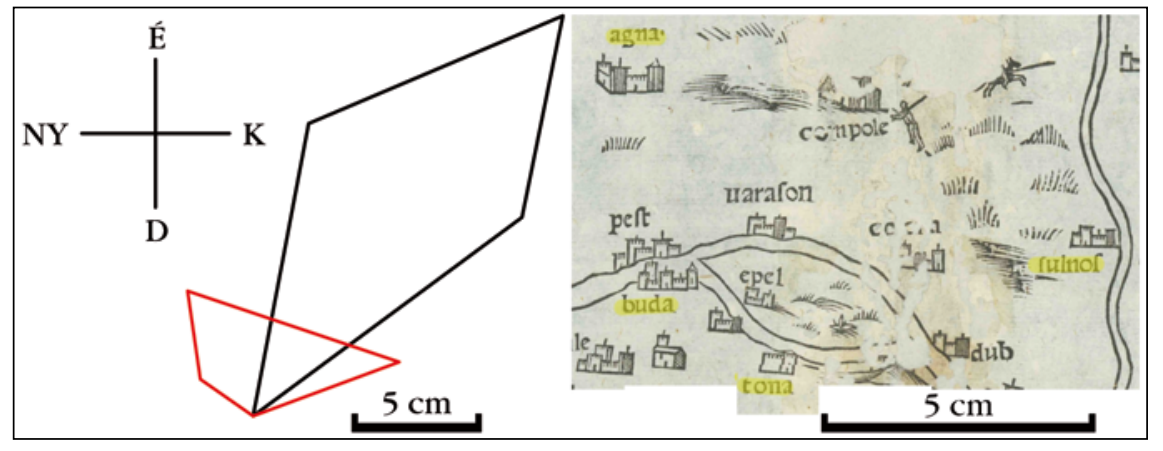

4. ábra. Tolna - Buda-Eger - Szolnok

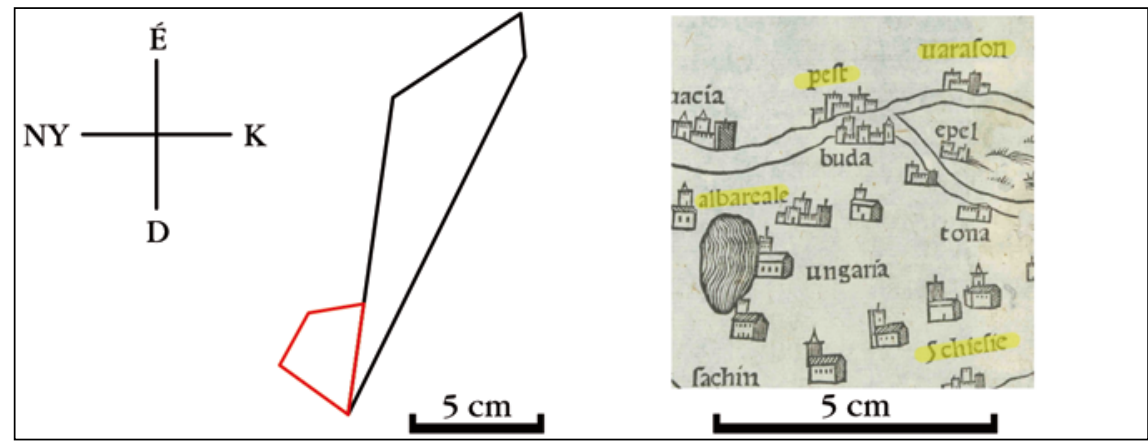

5. ábra. Pécs - Székesfehérvár - Pest - Dunavarsány

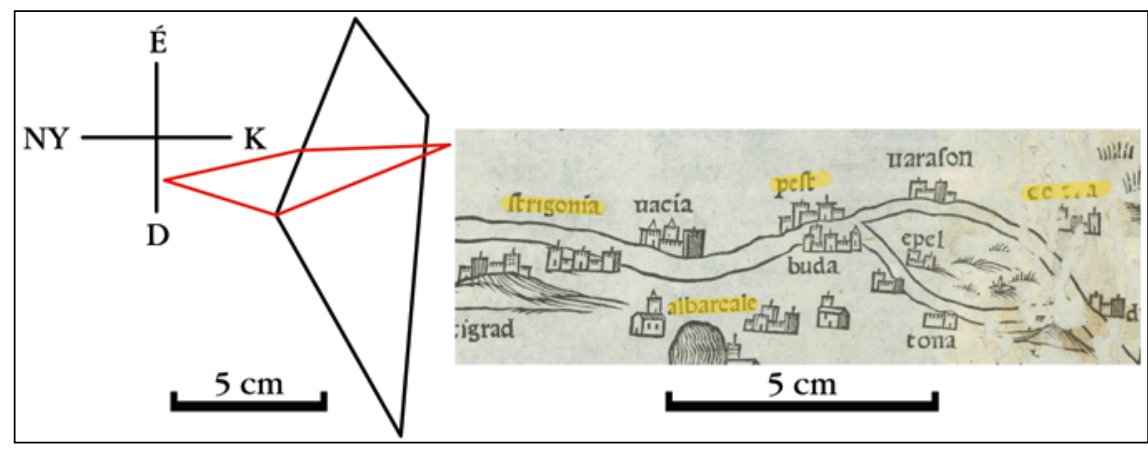

6. ábra. Székesfehérvár - Esztergom - Pest - Kalocsa

használt térkép legfontosabb adatai: Kárpát-medence. Méretaránya: 1:1 250 000, Lambert-féle kúpvetület. Készítette és kiadta az MH Kartográfiai Üzem Budapest, 1994.
A magyarországi részletek vizsgálata alapján megállapíthattuk azt, hogy mind a részletek alakja és azok iránya teljesen különböznek a modern térképtől. 
A Tiszántúl és Erdély keleti területére esô részlet alakjában és irányában szoros hasonlóságot mutat az összehasonlításul szolgáló modern térkép részletével. Az részlet alakjában az eltérés mértéke nem haladta meg a 15\%-ot, míg annak irányában a különbség elhanyagolható mértékú. E területrôl készült térkép méretaránya körülbelül 1:2 200000 lehetett. (7. ábra)

A 8. ábrán látható részlet alakja némileg hasonlít a mai modern térkép részletéhez, de iránya feltûnốen különbözó.

A 9. ábrán jelölt részletek összehasonlítása látványosan tanúskodik arról, hogy e térkép eredetileg több eltérő méretarányú részlet összeillesztésével készülhetett. Errôl árulkodnak a magyarországi részletek, - ahogy az a 10. ábrán is látható.

E feltevésünket még az is tovább erôsíti, hogy e térképen két Tisza és két Al-Duna szerepel. (Kék színnel kiemelve.) Az egyik Tisza az Északi-Kárpátokból eredt, mellette a jobb parton Szolnok, míg a bal parton Szolnoktól északra 'uarcan'18 helynév szerepel, és Titel térségében ömlött a Dunába. Míg a másik Tisza az Északkeleti Kárpátokban eredt, mellé került Szeged, és ismét feltûnt a 'uarcan' helynév is, de e folyó topográfiailag tévesen Nándorfehérvárral szemben ömlött a Dunába. Ez utóbbinak a mellékfolyója volt a Szamos, a Körös (névvel), a Maros, és az Al-Duna

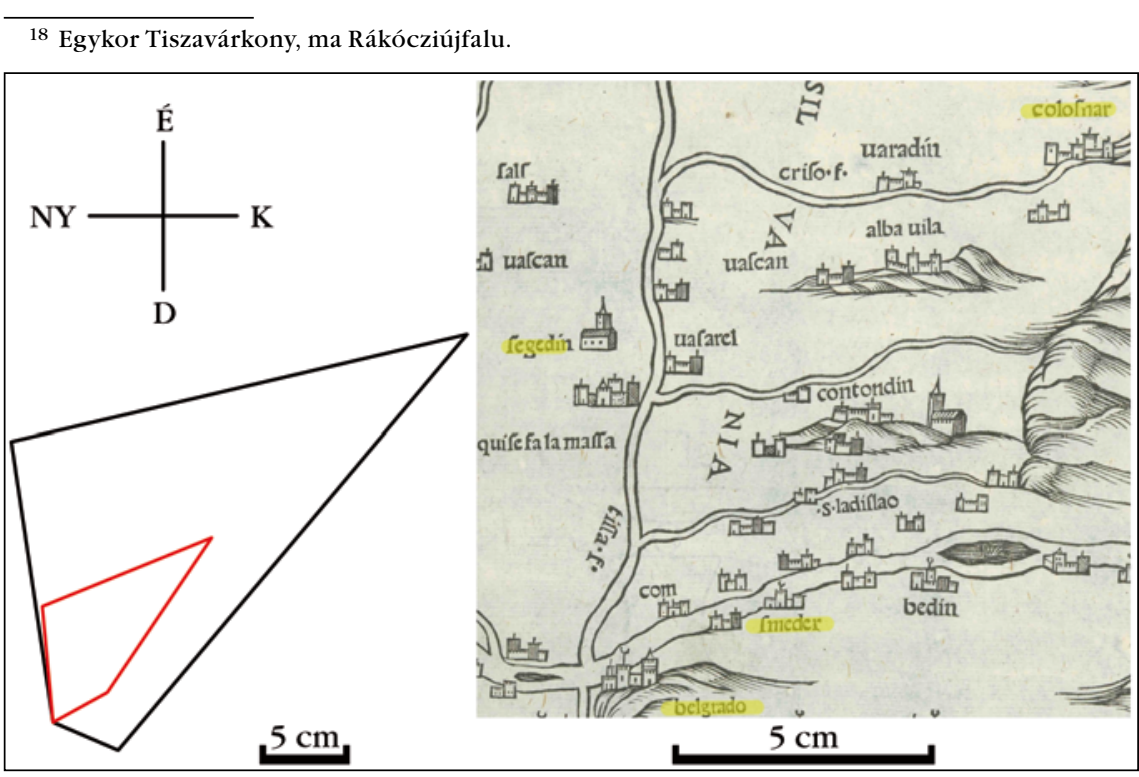

7. ábra. Belgrád - Szeged - Kolozsvár - Vég - Szendrö
Szörényvárig terjedó szakasza, ahol Szent László vár neve és jele is szerepelt. (11. ábra)

Vizsgálataink szerint a Dunántúl és káni területek még ptolemaioszi térképi alappal bírtak, míg a Tiszántúl és Erdély keleti részlete nem, erról a területről a szerzőnek már modern forrása lehetett. a Dráva-Száva folyók köze, illetve a bal-

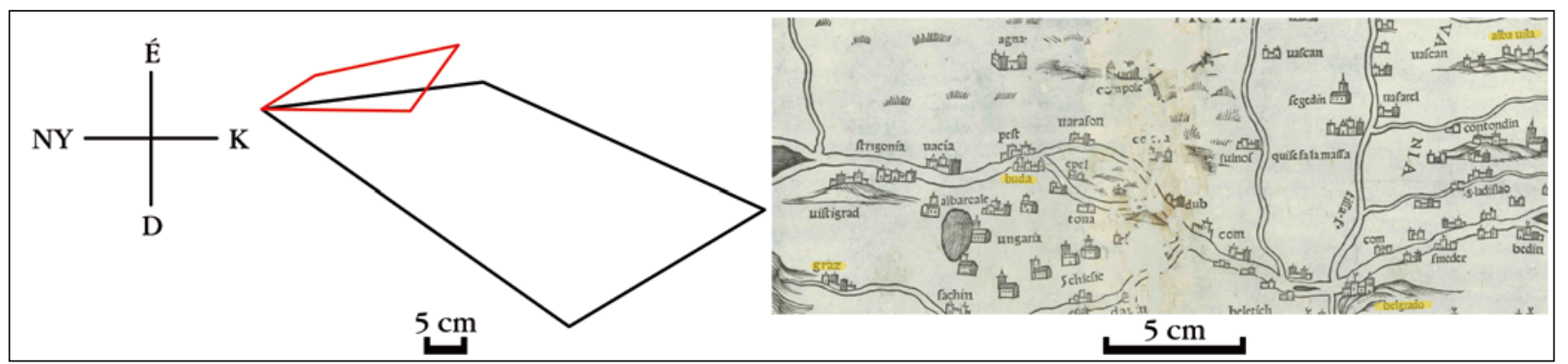

8. ábra. Graz-Buda - Gyulafehérvár - Belgrád

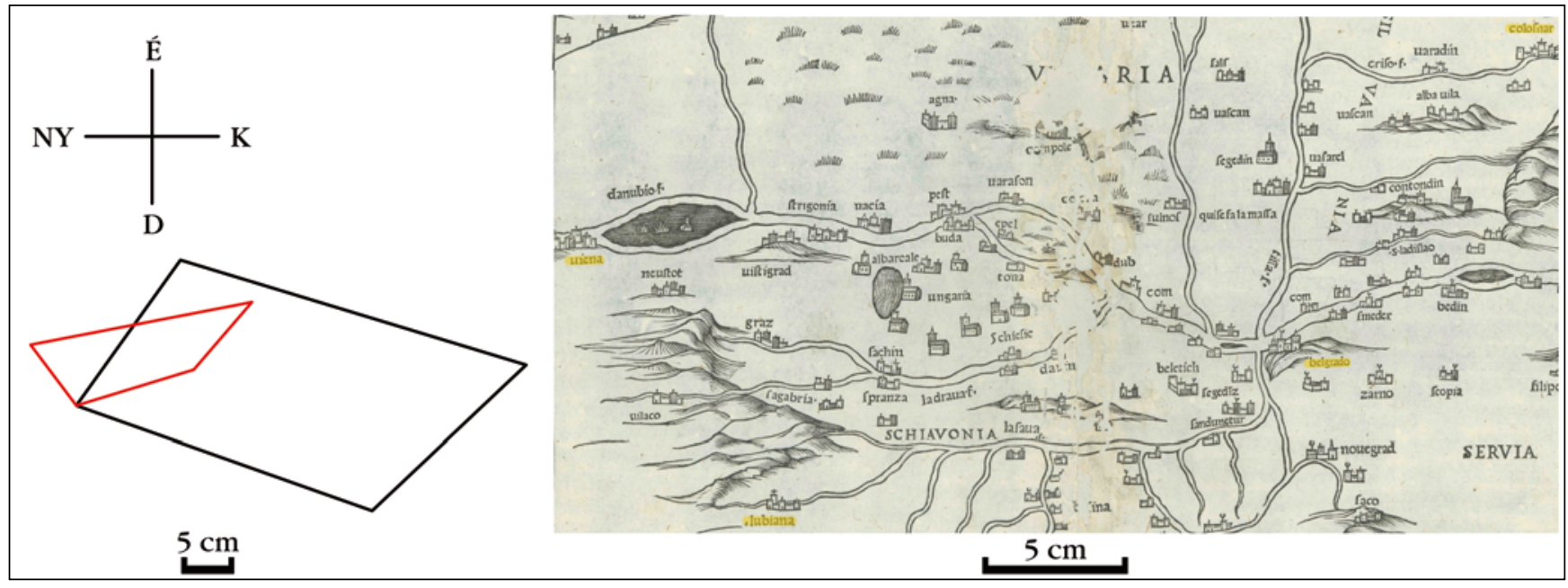

9. ábra. Ljubljana - Bécs - Kolozsvár - Belgrád 


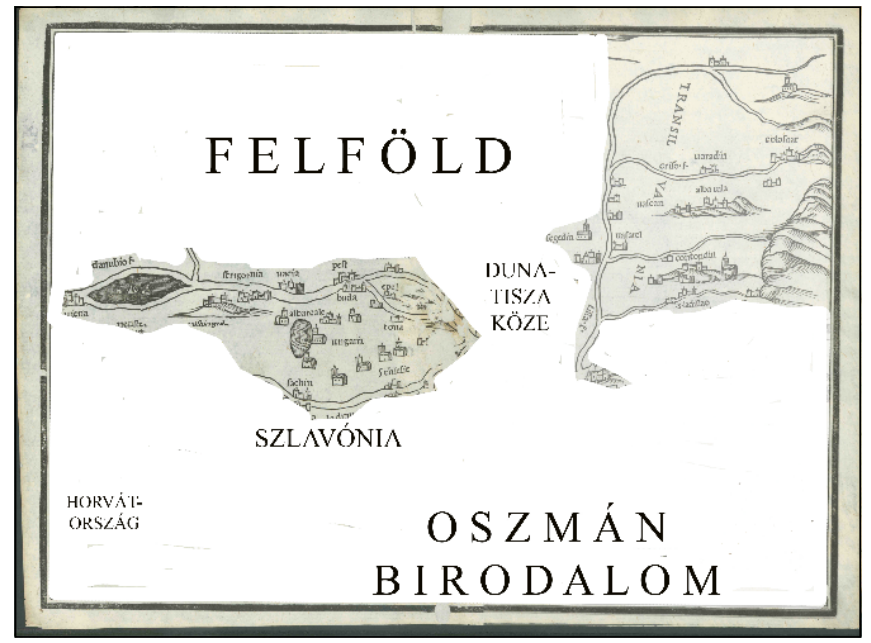

10. ábra. Az eltérố méretarányú részletek

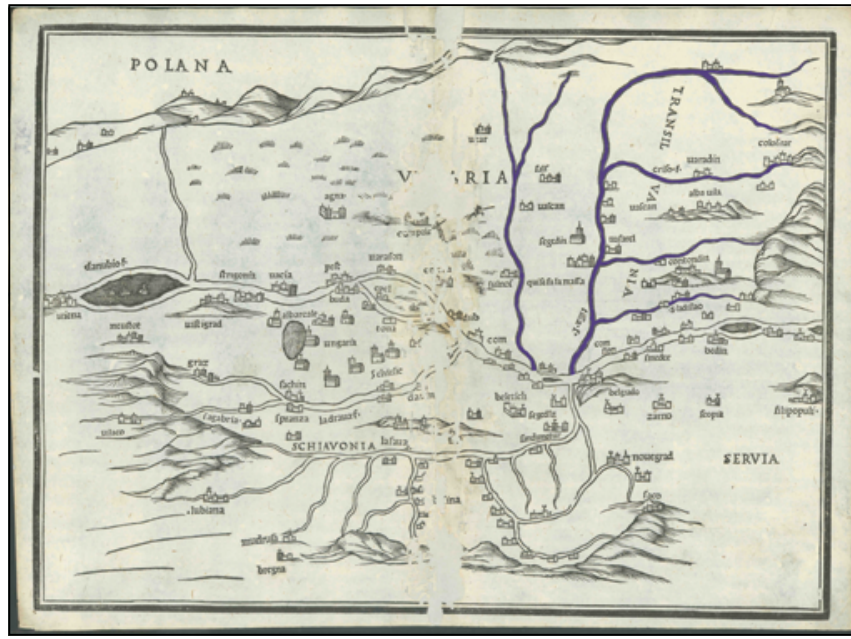

11. ábra. A két Tisza a térképen

\section{A topográfiai tartalom vizsgálatának eredményei}

\section{Települések ${ }^{19}$}

52 település jellel és névvel, míg 43 pedig csak jellel szerepel. A települések közül a Dunántúl térségében elôfordulók gyakran névvel és jellel és esetenként topográfiailag is a helyükön tûnnek fel. Ez alapján azt feltételezzük, hogy errôl a területrôl a térkép szerkesztôjének több ismerete lehetett. Azokat a településeket, amelyeket az Oszmán Birodalom meghódított, „félhold” jelöli. E jelölések alapján kétségkívül megállapíthatjuk azt is, hogy a Magyar Királyság területén félholddal (Szerémség) jelölt települések az 1521. évi török hódítások nyomán váltak az Oszmán Birodalom részeivé.

A jól azonosítható helynevek többsége a Dunántúlon található, míg a topográfiailag téves helyen szereplôk a Duna-Tisza közén, illetve az attól északra esố térségben. Az Északi-Kárpátokból eredő „Tisza folyó"mellett szereplố települések azonosítása kétséges.

\section{Egyéb földrajzi nevek}

A Duna felföldi mellékfolyói közül név nélkül a Vág szerepelt, míg a Drávától délre esố területek vízrajzának további azonosítása igen bizonytalan. A Balaton

\footnotetext{
${ }^{19}$ Beletinczvár, és tartozandóságaira nézve Raphaelbosniai püspök, szekcsôi Herczeg Fülöp és Pál közt egy részrôl, és Héder vári Lốrincz nádor közt más részrôl 1446 évben jószágpör volt, melyet Pálóczy László országbíró Raphael püspök és nevezett testvérei javára döntött el. In Pesty Frigyes: Az eltúnt régi vármegyék 1. Budapest, 1880. p. 271
}

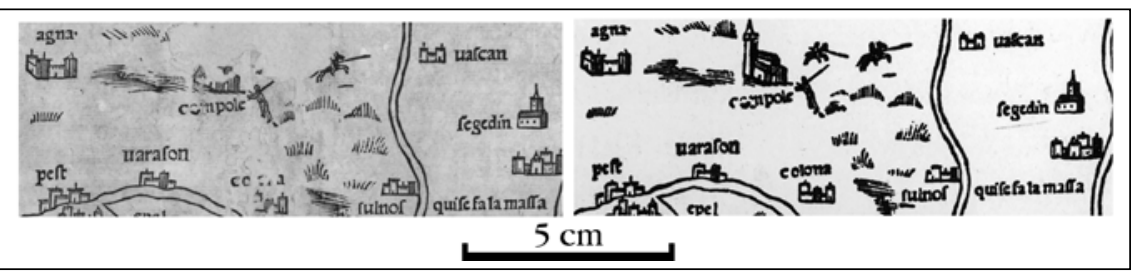

12. ábra. Katonák a térképen

szerepelt e térképen, míg a Szigetköz olyan jelekkel, mintha inkább az a Fertô lenne. A Csepel-sziget kiterjedése is feltûnốn nagy. A Duna folyó ábrázolása hasonlít a korabeli Európatérképen szerepló ábrázoláshoz, ahol a folyó a Kárpát-medencét szinte nyugatkeleti irányba szelte át, ahogy az például a Hartmann Schedel [1440-1514] LiberCronicarum ${ }^{20}$ címú, 1493-ban megjelent múvében található térképen is láthatjuk. (Lásd a címlapon.)

A vizsgált 1522-es térképen szerepel egy jelenet is, amely miatt e múvet Hrenkó Pál 1974-ben írt tanulmányában „elsố magyarországi haditérképnek" nevezte. (12. ábra) (Hrenkó 1974)

Kétségkívül a Kompolt település közelében elhelyezett jeleneten egy gyalogos és két lovas katona látható, ezt hadi eseménynek aligha nevezhetjük. A környezetében az olasz nyelvű feliratból az alábbiakról értesülhetünk:, quise fa la massa” „itt gyülekezik a tömeg".

Vajon a térkép egykori készítője e jelenettel mire akart utalni egy olyan mappán, amelyen az 1521-es esztendố török hódításairól kívánt tudósítani? A fenyegetố hírek érkezése után

\footnotetext{
${ }^{20} \mathrm{E}$ mú digitális változata megtekinthetô https://digi.ub.uni-heidelberg.de/diglit/ is00309000
}

júliusban elrendelték a mozgósítást, de a hadba szólítottak csak lassan gyülekeztek. (Oly nagymértékú volt a kincstár pénzhiánya, hogy az 1520. június 16-án elhunyt Bakócz Tamás hercegprímás értéktárgyait, kincseit és könyvtárát is elárverezték.) Az ostromlott vár felmentésére lassan szervezôdô hadsereg három menetoszlopba rendeződve indult Nándorfehérvár felé. A II. Lajos magyar király vezette sereg a Duna jobb partján menetelt a számára kijelölt gyülekezési pont felé, amely Tolna volt. Vélhetôen a király vezette sereg gyülekezési helye Pest tágabb térségében lehetett, és e jelenettel erre a katona tömegre utalhatott a térkép szerkesztôje. E seregben kapott helyet a cseh és a lengyel kontingens, valamint a dunántúli és szlavóniai csapatok, az utóbbiak a tolnai táborban csatlakoztak. Az e táborban összegyúltek létszáma már közel 20 ezer fốt tett ki. A király vezette menetoszlop Bátánál ${ }^{21}$ találkozott Szapolyai János [1487-1540] erdélyi vajda seregével. Az ecsedi Báthori István [148?-1530] nádor és temesi fốispán felelt a déli vármegyék lakosságának mozgósításáért, a számukra kijelölt gyülekezési központ Zenta volt, majd Pétervárad ${ }^{22}$

\footnotetext{
${ }^{21}$ Tolna és Báta is szerepelt a térképen.

${ }^{22}$ A Duna bal partján álló vár volt. Ma: Petrovaradin, Szerbia.
} 
Plihál Katalin: Egy „ismeretlen” nyomtatott térkép 1522-böl

\begin{tabular}{|c|c|c|c|c|}
\hline \multicolumn{5}{|c|}{ Települések } \\
\hline $\begin{array}{l}\text { Térképi } \\
\text { név }\end{array}$ & \begin{tabular}{|l|} 
Magyar neve \\
1914-ben
\end{tabular} & \begin{tabular}{|l} 
Magyar \\
névváltozata
\end{tabular} & Mai neve & Megjegyzés \\
\hline 5chiesie & Pécs & & Pécs & $\begin{array}{l}\text { Pécs német } \\
\text { nevének olasz } \\
\text { tükörfordítása } \\
\end{array}$ \\
\hline agna & Eger & & Eger & $\begin{array}{l}\text { topográfiailag } \\
\text { téves helyen }\end{array}$ \\
\hline albareale & Székesfehérvár & & Székesfehérvár & \\
\hline alba uila & Gyulafehérvár & & Alba Iulia, Románia & \\
\hline bat & Báta & & Báta & \\
\hline bedin & & Bodony & Vidin, Bulgária & \\
\hline beletich & Marót & & Morović, Szerbia & $\begin{array}{l}\text { Ma Marót } \\
\text { közelében van } \\
\text { az egykori Valkó } \\
\text { megyei Beletincz } \\
\text { várkastélya. }^{19} \\
\text { (Lelkes 2011) } \\
\end{array}$ \\
\hline belgrado & & Nándorfehérvár & Beograd, Szerbia & \\
\hline bregna & Brinje & Sokolac & Brinje, Horvátország & $\begin{array}{l}\text { Frangepán birtok, } \\
\text { majd a 16. század- } \\
\text { tól királyi vár }\end{array}$ \\
\hline buda & Budapest & & Budapest & \\
\hline compole & Kompolt & & Kompolt & \\
\hline colona & Kalocsa & & Kalocsa & \begin{tabular}{|l|} 
topográfiailag \\
téves helyen
\end{tabular} \\
\hline colosnar & Kolozsvár & & Cluj-Napoca, Románia & \\
\hline com & Bátmonostor & & Zmajevo, Szerbia & \\
\hline com & Keve & & Kovin, Szerbia & \\
\hline contodin & Ôscsanád & & Cenadu Vechi, Románia & \\
\hline dab & Dabas? & & Dabas? & \\
\hline dauin & $?$ & & $?$ & \\
\hline dub & $?$ & & $?$ & \\
\hline epel & Csepel & & Budapest & \\
\hline filipopuli & & & Plovdiv, Bulgária & \\
\hline graz & & & Graz, Ausztria & \\
\hline lubiana & & & Ljubljana, Szlovénia & \\
\hline mudrusa & Modrus & & Modruš, Horvátország & \\
\hline neustot & & Bécsújhely & Wienerneustadt, Ausztria & \\
\hline nouegrad & $?$ & & $?$ & \\
\hline pest & Budapest & & Budapest & \\
\hline sachin & Zákány & & \begin{tabular}{|l|} 
Zákány \\
\end{tabular} & \\
\hline Saco & & & Skopje, Észak-Macedónia & \\
\hline sagrabia & Zágráb & & Zagreb, Horvátország & \\
\hline sals & $?$ & & $?$ & \\
\hline sandunetur & $\begin{array}{l}\text { Mitrovica (Száva- } \\
\text { szentdemeter) }\end{array}$ & & $\begin{array}{l}\text { Sremska Mitrovica, } \\
\text { Szerbia }\end{array}$ & \\
\hline scopia & & Szófia & Szófia, Bulgária & \\
\hline segedin & Szeged & & Szeged & \\
\hline segediz & Mitrovica & & $\begin{array}{l}\text { Sremska Mitrovica, } \\
\text { Szerbia }\end{array}$ & \\
\hline s. ladislao & Lászlóvára & & Pescari, Románia & \\
\hline smeder & & Vég-Szendrô & Smederovo, Szebia & \\
\hline spranza & Kapronca & & Koprivnica, Horvátország & \\
\hline strigonia & Esztergom & & Esztergom & \\
\hline sulnos & Szolnok & & Szolnok & \\
\hline tona & Tolna & & Tolna & \begin{tabular}{|l|} 
topográfiailag \\
téves helyen \\
\end{tabular} \\
\hline uacia & Vác & & Vác & \\
\hline uaradin & Nagyvárad & & Oradea, Románia & \\
\hline uarason & Dunavarsány & & Dunavarsány & \\
\hline uasarel & Hódmezôvásárhely & & Hódmezôvásárhely & \\
\hline uascan & Rákócziújfalu & & Rákócziújfalu & Szolnok térs. \\
\hline uascan & Rákócziújfalu & & Rákócziújfalu & \begin{tabular}{|l|} 
Szeged térs. \\
\end{tabular} \\
\hline uiena & & Bécs & Wien, Ausztria & \\
\hline uilaco & & & Villach, Ausztria & \\
\hline uistigrad & Visegrád & & Visegrád & \\
\hline uzar & $?$ & & $?$ & \\
\hline zarno & & Zsarnó & Žrnov, Szerbia & \\
\hline
\end{tabular}

térségében táborozott a sajkásokat is tartalmazó serege, anélkül, hogy az ostromlottaknak bármi segítséget nyújtottak volna. II. Lajos szeptember elején értesült Nándorfehérvár elestéről. A hír hallatán elhatározták, hogy még ôsszel hadjáratot indítanak Zimony és Nándorfehérvár visszavételére. A várak visszavívásához új gyülekezési pontkén

\begin{tabular}{|l|l|l|}
\hline \multicolumn{3}{|c|}{ Egyéb földrajzi nevek } \\
\hline Térképi név & Magyar neve & $\begin{array}{c}\text { Megne- } \\
\text { vezése }\end{array}$ \\
\hline bosina & Bosznia & országnév \\
\hline criso f. & Körös folyó & víznév \\
\hline danubio f. & Duna folyó & víznév \\
\hline la draua f. & Dráva folyó & víznév \\
\hline la saua f. & Száva folyó & víznév \\
\hline POLANA & Lengyelország & országnév \\
\hline SCHIAVONIA & Szlavónia & országnév \\
\hline SERVIA & Szerbia & országnév \\
\hline tissa f. & Tisza folyó & víznév \\
\hline TRANSILVANIA & Erdély & országnév \\
\hline ungaria & Magyarország & országnév \\
\hline VNGARIA & Magyarország & országnév \\
\hline
\end{tabular}

Ujlakot ${ }^{23}$ jelölték meg, de végül a seregek a járvány és az idôjárás rosszra fordulása miatt dolgavégezetlenül feloszlottak.

\section{Vajon ki lehetett az 1522- es térkép készítóje?}

A Wolfgang Lazius térképeirôl szóló múben utalást találtunk egy olyan privilégium kérésére, amelyet Georg Tannstetter adott $b^{24}$. E kérvény szerencsénkre Bécsben az Osztrák Állami Levéltárban ma is megtalálható, és segítségével pedig az alábbiakról értesülhetünk. (OberhummerWieser 1906)

A Szent Birodalom nürnbergi kormányzata Georg Tannstetternek, az orvostudomány professzorának az alább leírt szabadságlevelet adta, és az alábbi kegyben részesítette nemrég miután ő, Tannstetter sietôsen egy térképet vagy tervezetet készített a keresztény és török

${ }^{23}$ Ma Ilok, Horvátotszág.

${ }^{24}$ Eredeti szöveg: „Georgen Thanstetter lerer der medicina hat das kaiserlich regiment in Heiligen Reich zu Nurnberg mit hernach geschribner freiheit begabt und begnadet neulich nachdem er, Thanstetter, in eil ain geographey oder entwerffung cristenlicher und thurckhischer lanndschafften gemacht, und die züge, so die christen wider die thurcken auch dieselben herwiderumb gethan haben, durch linien zum thail angezaigt, welche geographey er ytzt zupessern, und in gemaine trucken zu lassen vorhette, das ime sein Thanstetters Geographey nymant in funff jarn den negsten nach dato wider seiner willen nit nachdrucken failhaben noch verkauffen solle, bey pene zehen marck lotigs golds Actum an vierzehenten tag des monats decembris, in funfzehenhundert und zwey und zwanzigsten jars."

A térképkiadásra vonatkozó privilégium ma megtalálható Reichsregisterbücher Kaiser Karl V. Bd. 6. f. 128rv. Wien. In https:// www.archivinformationssystem.at/detail aspx?ID=161 
területekrốl, és a hadjáratokat a keresztényeket a törökök ellen és viszont vonalakkal részben berajzolta $^{25}$, amely térképet ố most kijavítani és közönségesen kinyomtattatni szándékozik, hogy Tannstetter térképét az ố akarata nélkül senki öt éven belül nem nyomhatja után és adhatja el tíz színarany márka büntetés terhe alatt. Adatott az 1522 . évben december hó 15 . napján. ${ }^{26}$

A fentiek értelmében Tannstetter ${ }^{27}$ készíttethette azt a vázlatos térképet, amelyet - védettség hiányában - mások kiadtak. (A privilégiumot nem vették figyelembe, vagy azt csak utána kérte?) Ahogy azt korábban már említettük, a Dunántúlon szereplố helynevek és helységek pontosabb topográfiai helyen találhatók, mint a térkép más területein szereplôk. Tannstetter több alkalommal is megfordult Magyarország e részén, például 1518-ban tanítványával Joachimus Vadianussal [1484-1551] azért utazott Budára, hogy ott egy csillagászati jelenséget figyeljenek meg. Ma már tudjuk, hogy az utazás célja az 1518. június 8-ra Johannes Regiomontanus [1436-1476] által Budára elốre jelzett teljes napfogyatkozás megfigyelése volt (Wolf 1892). A középkori csillagászok azonban nem feltétlenül a teljes napfogyatkozásokra voltak kíváncsiak, hanem arra, hogy az elốre számított adatok a valósággal mennyire egyeztek. Más részrốl a korabeli hadi eseményekben érintett településekrốl Tannstetter rendelkezhetett szinte naprakész információkkal. A térképen ábrázolt térségben történt hadi események iránti fokozott érdeklôdés miatt kért szellemi tulajdonára határozott idejû védelmet, bár e mû́ javított változatából példányt nem ismerünk, de annak kiadására bizonnyal 1523-ban kerülhetett sor. A hadi cselekmények egyre fenyegetôbbek voltak a Velencei Köztársaságra és az osztrák örökös tartományokra is. E Tannstetter által szerkesztett térkép 1522 novemberében már a nürnbergi birodalmi

\footnotetext{
${ }^{25}$ Kiemelés tốlem.

${ }^{26} \mathrm{Az}$ eredeti szöveget megtalálta, leírta, és fordította dr. Fazekas István.

${ }^{27}$ In http://de.wikipedia.org/wiki/Georg Tannstetter (2010.03. 17.).
}

gyưlés résztvevổihez is eljutott. Forrásaink szerint 1523 januárjában a Német-római Birodalom hadügyi albizottsága „aus der Hungerischen mappa” alapján készítette el javaslatát a Magyarországra küldendố német segédcsapatok elhelyezésére vonatkozóan (Tóth 1927-28). (Az 1523 nyarán Magyarországra érkezett német birodalmi segédcsapatok a Szávaszentdemeter-Nagyolaszi ${ }^{28}$ Rednek ${ }^{29}$ térségében augusztus 4-e és 7-e között mezei ütközetben vettek részt. Ebben az összecsapásban a keresztény seregek gyốzelmet arattak, a törökök pedig vereséget szenvedtek, így az ország déli határain egyelốre enyhült a hódítók katonai nyomása, és ez a kegyelmi állapot 1526. augusztus 29-ig állt fenn (Kubinyi 1978). Tannstetter térképét nyilván mások is kiadhatták, jelenleg csak olasz kiadásokból ismerünk példányt.

\section{Vajon e szóban forgó térkép nyomódúcát ${ }^{30}$ ki és hol készíthette?}

Az e térképpel korábban foglakozó Hrenkó Pál a szóban forgó térképet Giovanni Andrea de Vavassore ${ }^{31}$ [?-1572] múvének tulajdonította, ám e feltételezés jelen ismereteink szerint nem igazolható, e mú nyomódúcán azún. sziturációt fába vésték, míg a feliratok betû́beültetéssel készültek (Hrenkó 1974). A fa nyomódúcok használatának az egyik legjelentốsebb elốnye a rézlemezrốl történt

\footnotetext{
${ }^{28}$ Mandjelos, ma Manđelos, Horvátország.

${ }^{29}$ Ma Vrdnik, Szebia.

${ }^{30}$ Lásd még: Plihál Katalin: A térképnyomtatás müvészete a 19. század végéig. Budapest, 2008. CD-ROM

${ }^{31}$ Életérốl sajnos ma nagyon keveset tudhatunk. Velencében élt, és dolgozott. Nevéhez több térkép készítése és kiadása köt hetố. Pályafutását nyomdászként kezdte, de 1530 körül e mesterségével felhagyott, és mint mûvész és betû̉metszổ kezdte pályáját. 1523-as testamentumában magát „incisorfigurarum" festốcéh tagja. 1544-1572 között csak Giovanni Andrea nevet viselte. Valvassore térképei ritkák. David Woodward: The Italian Map Trade, 1480-1650. In The History of Cartography. Vol. Three. Cartography in the European Renaissance. Part. 1. Ed. by David Woodward. Chicago \& London. 2007. 780. p. Rodney SHIRLEY: Valvassore\&Pagano. The Cartographic Output of Two Venetian Map-makers. In Journal of the Internationa Map Collectors' Society. 2009. 31-39. pp.
}

nyomtatással szemben az volt, hogy ugyanazzal a nyomdaberendezéssel lehetett nyomtatni, amivel a könyvek is készültek, míg a rézlemez esetén más berendezésre volt szükség. Fametszéssel készült a térkép rajzi része, míg a megírások mozgatható nyomdai betûkbbốl. A nyomdászok folyamatosan keresték annak a lehetôségét, hogy a fa nyomódúcok használatával a már meglévố elốnyük megtartása mellett gyorsan és olcsóbban tudjanak térképeket sokszorosítani. Így került sor arra a technológiai újításra, amelynek során a térkép rajzi részét továbbra is véséssel alakították ki, míg a megírásokat nyomdai betûkbốl. A mozgatható betûket a nyomódúc átréselésével kiképzett árkokba helyezték, azokat apró ékekkel, illetve gyantával tudták a nyomtatás során „helyben maradásra” bírni. A módszer elốnye a nyomódúc gyorsabb elkészítése mellett az volt, hogy a térképek szerkesztối a különbségeket a nevek betûnagyságával is jelölhették, az egységes íráskép kialakítása egyszerûbb, könnyebb és gyorsabb volt. A fenti eljárás további haszna volt az is, hogy az így készített nyomódúcot a különbözố nyelvû́ kiadásokhoz könynyebben lehetett adaptálni. Hátránya volt viszont, hogy a dúc használata során egy-egy betû́ kiesett, ezeket néha nem oda illố betû́vel pótolták, ezért egy néven belül esetenként latin és gót betûk akár keveredve is elốfordulhattak. Idốnként a kihullott betûk pótlása elmaradt, és ezért a nyomukban „új” nevek keletkeztek. Például Wolfgang Lazius 1556-ban megjelent Magyarország-térképén ${ }^{32}$, amelyet Michael Zimmerman nyomtatott Bécsben; a Crisiensis (Körös) megye nevébốl a 'c' betû́ kihullásával „új megyenév" 'Risiensis' lett.

A vizsgált térképen elốforduló betûk típusa antikva, amelyet elsốként a velencei Aldus Manutius [1447/1452-1515] és a bolognai Francesco Criffo [1450-1518] használtak nyomtatványaik készítése során. ${ }^{33}$

\footnotetext{
${ }^{32}$ Regni Hungariae descriptio vera, Des Khünigreichs Hungernsampt seinen eingeleibten Landengrundtliche unnd Warhafftige Chorographicabeschreybung. M. [1:540 000]. Vienna, $1556,76 \times 129 \mathrm{~cm}$. ${ }^{33}$ https://stilustan.files.wordpress.com/ 2014/09/betc5b1tc3b6rtc3a9net.pdf
} 


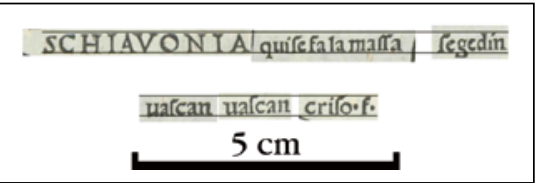

13. ábra. Nagybetûs és kisbetûs feliratok a térképen

E térképen a feliratok vagy tisztán nagybetúből, vagy kisbetúből készültek. (13. ábra)

A képen látott nagy- és kisbetûk magassága azonos, ez pedig csak abban az esetben lehetséges, ha a nyomtatás során eltérô betúkészlet részeit használták. A nyomdászatban használt mértékrendszer (Didot-rendszer) szerint valószínúleg a nagybetû́k mérete két ciceró, míg a kisbetúké három ciceró lehetett. A fentiek alapján azt vélelmezzük, hogy ez esetben csak a betût ültették be egy arra kialakított árokba, így nem kellett a teljes nyomódúcot átréselni azért, hogy a feliratokat elhelyezzék. Az azonos méretû́ betúknek azonos méretú árkokat kellett készíteni, ez megkönnyítette a nyomódúc elôkészítését. A betûket egyenként fenyőgyantával ragasztották be, így azok közül csak az hiányzott, amelyik kihullott. (A fenyốgyanta kellốen rugalmas anyag volt ahhoz, hogy a nyomtatás során fellépố terhelést elviselje.) Nem kizárt, hogy ezt a térképnyomtatási technológiai megoldást fejleszthette tovább Petrus Apinus [1495-1552] a Tabula Hungarie nyomtatása során, amely így a világon az elsô sztereotípia használatával sokszorosított térkép.

Az Országos Széchényi Könyvtár Térképtárában található egyetlen ismert példány vízjele Briquet katalógusában nem található, csak egy hozzá hasonló fordul elô, amely egy Villachban $^{34}$ (Karintia) múködô papírmalomé volt 1535 körül (Szathmáry 1992). (A nyomdák számára ugyan papírt ritkán szállítottak nagyobb távolságra, de nem igazán tudjuk pontosan azt, hogy e szempontból a 16. század elején mi számított nagyobb távolságnak.) A földrajzi nevek írása alapján 'belgrado', '5chiesie', 'la draua f.' stb. bizonyos,

\footnotetext{
${ }^{34}$ Villach az Alpok térségén át a Rómába vezetô fontos kereskedelmi útvonal mellett található.
}

hogy e térkép olasz nyelvterületen látta meg a napvilágot. A térkép nyelve, a nyomtatásnál használt betú típusa, valamint a papír vízjele alapján az e helyen bemutatott térkép kétségkívül valamely itáliai fametszô munkája, de ebben a pillanatban metszóként senkit sem tudunk megnevezni. A magyar szakirodalomban elôforduló lehetséges készítô, Giovanni Vavassore velencei fametszố e térképpel kapcsolatba azért nem hozható, mert jelen ismereteink szerint betúbeültetéssel sem térképet, sem más illusztrált képet nem készített.

Sajnálatosan nincs adatunk arról sem, hogy e szóban forgó mú megjelenési helye hol lehetett, és azt sem tudjuk, egykor kinek a költségén látta meg a napvilágot. A 16. század elején az Európát meghódítani akarók jelentette fenyegetésekről a korabeli röplapok és a viszonylag periodikusan megjelenô újságok elốzményei tájékoztatták az érdeklôdôket. ${ }^{35}$ Nem kizárt, hogy a jelen vizsgálat tárgyát képezố cím nélküli térkép is egy ilyen kiadványba illesztve látta meg egykor a napvilágot. Tannstetter már idézett kérvénye is alátámasztja a feltevésünket, mivel azt a könyvekre vonatkozó privilégiumok közé jegyezték be. ${ }^{36}$ (Sajnálatos, de csak a térképek kiadására vonatkozó engedélyeket akkor még nem jegyezték be. Így a Tabula Hungarie ... Ingolstadt, 1528. térkép kiadására a privilégiumot a térképen szereplố megírás szerint Tannstetter kapta, de erról a korabeli dokumentumok napjainkra semmi adatot nem ôriztek meg.) Szöveges magyarázat hiányában, az e térképen szereplô helyek jelölései és nevei önmagukban kevés ismeretet tudtak közvetíteni. Egyébként Nándorfehérvár eleste rémületet váltott ki Európaszerte, ahogy arról a korabeli dokumentumok alapján értesülhetünk. Mert nemcsak egy vár cserélt gazdát,

\footnotetext{
${ }^{35}$ Ilyenek például az alábbiak is: Jos Dennäer [149?-15??] nyomtatott: „All hie ist abkuntefet das Schlosz Kriechisch Weysenburgk und das Steteyn in aller form und geschiekkayt. Augsburg, 1522 . Turcken puechlein ein nutzlich Gesprech oder unterrede etlicher personen geendet im Metzen 1522.

${ }^{36} \mathrm{Az}$ adatok tisztázását dr. Oross András levéltári rezidensnek köszönöm.
}

hanem a folytonos háború lehetôsége immár testközelivé lett Európa szívében.

\section{Irodalom}

Brichzin, Hans 1992. Megjegyzések az elsố nyomtatott Magyarország térképrôl (1522). In Cartographica Hungarica, 1. sz. pp 37-38.

Cseh Valentin 2010. Nándorfehérvár szerepe a déli végvárrendszerben. 1417-1521. In Várak kastélyok templomok - történelmi és örökségturisztikai folyóirat. decemberi szám. pp. 29-31.

Hrenkó Pál 1974. Magyarország legrégebbi nyomtatott térképe? In Geodézia és Kartográfia, 26. évf. 6. sz. p. 450

Kiss Lajos 1889. Nándorfehérvár bukása (1521). In Hadtörténelmi Közlemények, p. 604 .

K. Obermayer Erzsébet - Horváth István Károly 1959. Macedóniai László. Egy humanista élete és múködése a Mohács körül évtizedekben. In Századok, pp. 773-799.

Klaniczay Tibor (válogatás, a szöveggondozás és jegyzetek) 1982. Macedóniai László: Magyarország legkegyelmesebb királya ... In Janus Pannonius - Magyarországi humanisták. Budapest, pp. 902-912

Kubinyi András 1978. A SzávaszentdemeterNagyolaszi gyốzelem 1523-ban. Adatok Mohács előzményéhez. In Hadtörténelmi Közlemények, pp. 184-220.

Lelkes György 2011. Magyar helységnév-azonosító szótár. Budapest, p. 128.

Oberhummer, Eugen - von Wieser, Franz 1906. Wolfgang Lazius Karten der österreichischen Lande und des Königreichs Ungarn aus den Jahren 1545-1563. Im Auftrage der k. k. geographischen Gesellschaft in Wien zur Feier ihres fünfzigjährigen Bestandes Hrsg. Innsbruck, p. 37.

Pálosfalvi Tamás 2005. Nikápolytól Mohácsig. 1396-1526. Budapest, pp. 180-190.

Szathmáry Tibor 1992. Hazánk egyik legrégibb nyomtatott térképe. II. rész. In Cartographica Hungarica, 2. szám p. 3., 6.

Tóth Zoltán 1927-1928. Bonfini 1490 utáni adatai a fekete seregrốl. In Századok, p. 55.

Veszprémi László 2010. Nándorfehérvár ostromai - a reneszánsz hadügyi elmélet kezdetei Magyarországon. In Várak kastélyok templomok - történelmi és örökségturisztikai folyóirat decemberi szám pp. 32-35.

Wolf, Rudolf 1892. Handbuch der Astronomie, ihre Geschichte und Litteratur, II. köt. Zürich, p. 712 .

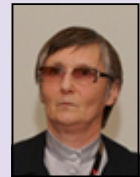

Dr. Plihál Katalin térképtörténész

plihal1948@gmail.com 